\title{
KRITIK SOSIAL \\ (DALAM PERSPEKTIF DAKWAH)
}

\author{
Oleh : Alamsyah \\ Dosen Fakultas Dakwah dan Komunikasi UIN Alauddin \\ Email : alamsyah@gmail.com
}

\begin{abstract}
Dakwah merupakan upaya mengajak manusia ke jalan Tuhan yang termanifestasi dalam pencerminan segala bentuk kemaslahatan dan pencegahan kemungkaran. Dakwah disamping menjadi tugas yang sarat dengan dimensi Ilahiyat juga berimplikasi Insaniyat. Mewujudkan sesuatu yang ma'ruf menjadi intrinsic manusia dan menjadi fokus dakwah. Mencegah kemungkaran juga menjadi obsesi setiap orang yang sadar akan nilai-nilai universal.

Dinamika dalam kehidupan sosial dengan berbagai dimensi dan implikasinya, membuat dakwah semakin tertantang dan tangan dakwah semakin kompleks. Tanpa tantangan, dakwah akan statis dan mustahil akan mampu memberikan solusi terhadap masalahmasalah yang rumit dihadapi dalam kehidupan sosial. Tantangan pada hakekatnya, merupakan bagian dari kritik sosial yang muncul sebagai kreatifitas untuk produktifitas. Kritik sosial sangat mempengaruhi format kebijakan dalam menentukan arah kehidupan bermasyarakat dan bernegara.

Kritik sosial adalah sifat berbeda pendapat yang muncul dari penilaian yang kritis terhadap situasi. Hal ini sangat diperlukan demi mencegah timbulnya kesewenangwenangan. Dalam konteks demikian, kritik sosial sekadar teknik untuk secara terbuka saling menunjukkan sikap yang sebenarnya dalam beramar ma'ruf nahi munkar.
\end{abstract}

\section{Keywords :}

Dakwah, Dinamika, Kritik dan Kreatifitas

\section{Pendahuluan}

Abad ke-21 di anggap sebagai abad kebangkitan agama-agama. Ilmu pengetahuan dan teknologi (IPTEK) yang dihasilkan oleh kemampuan logika manusia, pada batas-batas tertentu (dengan tidak menafikan dampak positifnya) telah menimbulkan problema baru berupa kegelisahan kemanusiaan. Potensi dehumanisasi tersebut telah menumbuhkan kesadaran transendental umat mausia untuk kembali kepada pangkuan agama yang sejuk dan manusiawi. Hal ini menunjukkan, bahwa manusia tidak akan survive bila nilai-nilai agama tidak diaktualisasikan dalam kehidupannya.

Untuk itu, agama perlu memberi jawaban yang komprehensif dan konsisten terhadap banyak masalah hidup dan kehidupan. Semangat keagamaan yang ingin dibangun, bukan saja kemasan ibadah ritual yang formalistic, melainkan semangat keagamaan yang substantive, sehingga mampu memberikan konstribusi konkrit dalam dinamika peradaban manusia. 
Dalam agama Islam, segala usaha untuk mengaktualisasikan ajaran Islam dalam semua segi kehidupan dapat dikategorikan sebagai aktifitas dakwah. Dakwah Islam berfungsi sebagai pemandu moral perjalanan hidup umat manusia. Dakwah menjadi elemen penting dalam melakukan sosialisasi dan internalisasi ajaran Islam kedalam realitas empirik.

Pada hakekatnya, dakwah Islam merupakan aktualisasi imani (teologis) yang dimanifestasikan dalam suatu system kegiatan manusia beriman dalam bidang kemasyarakatan secara teratur untuk mempengaruhi cara merasa, berfikir, bersikap dan bertindak manusia pada dataran kenyataan individual dan sosio-kultural dalam rangka mengusahakan terwujudnya ajaran Islam dalam semua segi kehidupan dengan menggunakan cara tertentu.

Proses aktualisasi nilai iman pada semua dataran kenyataan manusia merupakan suatu upaya dalam rangka merealisir fungsi kekhalifahan. Yaitu suatu upaya membebaskan umat manusia dari sistem kehidupan yang dhalim karena adanya tirani, hilangnya ukuran kebenaran, matinya lembaga-lembaga demokrasi dan hak asasi tidak diindahkan lagi.

Kritik sosial merupakan wahana bagi perubahan sosial (amar ma'ruf nahi munkar). Kritik sosial berperan mengoreksi praktek-praktek yang berlaku ditengah-tengah kehidupan masyarakat, apakah sesuai dengan norma-norma agama atau tidak. Proses ini terdiri dari pengubahan sistem merasa, berpikir, bersikap dan bertindak. Tanpa kritik sosial, maka kondisi masyarakat hanya mempertahankan status-quo, sehingga menjadi apatis tanpa dinamika yang konstruktif.

Kritik sosial merupakan sifat berbeda pendapat yang muncul dari penilaian yang kritis terhadap situasi. Perbedaan pendapat tersebut sangat diperlukan demi menjaga penyalahgunaan wewenang dalam menjalankan fungsinya.

Tulisan ini akan membahas kritik sosial dalam perspektif dakwah. Pada hakekatnya, dakwah sebagai agen perubahan sosial, esensinya dakwah sudah terkandung unsur kritik, dalam melaksanakan amar ma'ruf nahi munkar di tengah-tengah kehidupan masyarakat. Dakwah mengabsahkan perilaku yang sesuai dengan norma Islam dan mengoreksi perilaku sosial yang menyimpang. Karena itu, dakwah tidak dapat dipisahkan dengan kritik sosial. Masalahnya adalah bagaimana kritik sosial itu, dimana letak eksistensinya dalam struktur sosial, bagaimana proses kritik sosial itu dan apa kontribusinya dalam pelaksanaan dakwah. 


\section{Pembahasan}

\section{A. Pengertian dan Ruang Kritik Dalam Struktur Sosial}

Dalam ilmu sosiologi, teori-teori sosial yang berkembang, baik teori sosial klasik maupun teori sosial kontenporer, selalu memberi ruang kritik soaial sebagai salah satu elemen bagi dinamika sosial dan seterusnya melahirkan transformasi sosial.

Dalam bahasa Arab, Kritik sosial ada hubungannya dengan lafadz “ " المعارض “ yang berarti kebebasan untuk mengkritik dan mengontrol kegiatan pemerintah atau decision making adalah system dasar pemerintahan Islam yang memberikan hak kepada individu dan kelompok untuk mengkritik, mengubah dan mengungkapkan pelanggaran, bahkan jika ia bertentangan dengan pihak yang berkuasa. ${ }^{1}$

Kritik sosial terkait dengan kata "al-Tafriq", yakni mengisolasi kondisi-kondisi yang negative dari yang positif agar yang positif tumbuh dan berkembang secara progresif tanpa dihambat oleh rintangan-rintangan yang destruktif.

Bila dilihat peran dakwah sebagai agent of change, maka kritik sosial sejalan dengan al-Tafriq. Kata "kritik " itu sendiri secara harfiah juga berarti " memisahkan". Memisahkan yang benar dari yang salah. makna tersebut sejalan pula dengan salah satu nama Alquran, yaitu al-Furqan, yang berarti memisahkan antara yang haq dengan yang bathil. Dari makna tersebut nampak bahwa keberadaan Islam merupakan langkah kritis terhadap agama, tradisi sosial serta tatanan yang berlaku pada masa pra Islam. Bahkan dimanapun Islam berada selalu bersikap kritis terhadap situasi yang berkembang.

Jika kritik sosial diimplementasikan dalam kehidupan masyarakat, maka akan lahir pengertian amar ma'ruf nahi mungkar, sedang amar ma'ruf nahi munkar merupakan salah satu konsep yang sangat urgen dalam Alquran karena berkaitan langsung dengan hakekat keberagamaan Islam.

Istilah amar ma'ruf nahi munkar sudah sangat popular dikalangan masyarakat karena berkaitan erat dengan kata dakwah, perjuangan dan biasanya disebut sebagai semangat tertentu. Misalnya semangat perjuangan, karena itu istilah tersebut mengandung konotasi tertentu. Seperti halnya perjuangan menentang korupsi, prostitusi, narkoba, masalah-masalah sosial, keagamaan, ekonomi, politik, pendidikan dan sebagainya.

\footnotetext{
${ }^{1}$ Lihat Sahar L Hasson (Ed) Memilih Partai Islam Visi dan Presepsi ( Cet. I Jakarta : Gema Insani Pres, 1998 ),h.13
} 
Perjuangan untuk mengkritisi hal-hal tersebut biasa disebut amar ma'ruf nahi mungkar (dakwah).

Ibnu Taimiyah mengemukakan bahwa amar ma'ruf nahi mungkar merupakan tujuan yang sangat komprehensif, termasuk didalamnya mengajak melaksanakan praktikpraktik sosial politik dan ekonomi yang bermanfaat dan mencegah praktik-praktik sosial politik dan ekonomi yang buruk. ${ }^{2}$

Amin Rais menegaskan perjuangan menegakkan amar ma;ruf nahi munkar selalu mengundang resiko. Memerintahkan yang ma'ruf, tidak beresiko, tetapi menganjurkan nahi mungkar, seefeknya cepat atau lambat akan bersinggungan dengan kekuasaan. Memerintahkan yang bagus, tanpa resiko, tetapi melarang supaya tidak melakukan yang terlarang atau hal yang buruk, akan berhadapan dengan senang melakukannya. ${ }^{3}$

Dengan demikian istilah amar ma'ruf nahi munkar mengandung konotasi "berjuang menentang" membasmi atau memberantas yang konotasinya adalah bentuk negative. Kritik sosial, adalah sosialisasi mengenai masalah-masalah yang dianggap penting sebagai peringatan terutama untuk mengantisipasi berbagai kondisi krisis yang berkepanjangan.

Secara makro, eksistensi amar ma'ruf nahi mungkar sebagai bagian dari kritik sosial senantiasa bersentuhan dan bergelut dengan realita sosial yang mengitarinya. Dalam perspektif historis, pergumulan dakwah Islam dengan realitas sosio-kultural menjumpai dua kemungkinan. Pertama, dakwah Islam mampu memberikan output (hasil, pengaruh ) terhadap lingkungan dalam arti memberi dasar filosofi, arah, dorongan dan pedoman perubahan masyarakat sampai terbentuknya realita sosial yang baru. Kedua, Dakwah Islam dipengaruhi oleh perubahan masyarakat dalam arti eksistensi, corak dan arahnya. Ini berarti bahwa aktualisasi dakwah ditentukan oleh sistem sosio-kultural. Dalam kemungkinan kedua ini, system dakwah dapat bersifat statis atau ada dinamika dengan kadar yang hampir tidak berarti bagi perubahan sosio-kultural.

Pada bagian ini, dikemukakan pula beberapa teori sosial dalam posisi kritik sosial, didalamnya adalah : Auguste Comte ( lahir di Montpellier, Perancis tahun 1798),

\footnotetext{
${ }^{2}$ Lihat, A.A. Islahi, Konsep Ekonomi Ibnu Taimiyah ( Surabaya : PT. Bina Ilmu, 1979 ),h.220

${ }^{3}$ Lihat Amin Rais, Membangun Politik Adi Luhung, Membumikan Tauhid Sosial Menegakkan Amar Ma'ruf Nahi Mungkar ( Cet. I : Bandung : Zaman Wacana Mulia, 1998),h.219
} 
mengemukakan perkembangan masyarakat dalam tiga tahap, yaitu tahap mitis ( sering pula disebut tahap religious), tahap metafisis dan tahap positif, ${ }^{4}$

Pada tahap mitis, kritik sosial hampir tidak ada karena masyarakat menyelesaikan problema kehidupannya berdasarkan pada otoritas mitis yang di terima sebagai sumber nilai untuk membentuk tatanan sosial. Masyarakat mitis masih pra-rasional sehingga tertutup terhadap kritik. Pada tahap metafisis, kritik sosial mulai ada, karena masyarakat sudah mulai rasional, tetapi kritik yang muncul sangat abstrak. Tidak menyentuh langsung masalah -masalah praktis dan pragmatis yang muncul dalam masyarakat. Pada tahap positif, masyarakat mulai terbuka, dinamika sosial berkembang pesat, sehingga memberikan peluang lebih besar lagi terhadap kritik sosial.

Karl Marx (lahir di Trier, Jerman tahun 1818 ), membedakan kelompok sosial atas dua bagian, yaitu kelompok proletariat dan kelompok borjuis. Kelompok proletariat adalah lapisan masyarakat bawah sebagai anti thesis terhadap kaum borjuis sebagai kelompok masyarakat atas (konglomerat). Menurut Marx, sudah menjadi determinisme historic bahwa dari kalangan proletariat lahir kelompok-kelompok kritis yang memberi tindakan oposisi terhadap kaum borjuis. ${ }^{5}$ Kritik dan oposisi memunculkan konflik-konflik sosial yang menurut Marx sebagai wahana bagi perubahan sosial. Pergolakan akibat kritik dan oposisi semakin lama semakin naik ketaraf lebih tinggi. Setiap taraf kritik memperlihatkan kemajuan-kemajuan yang berarti dalam satu stadium kritik, akhirnya sampai pada stadium tertinggi, yakni tahap sistesis yang tidak ada lagi antitesisnya. Pada stadium ini terjadi social balance (keseimbangan sosial yang sempurna ) atau aquilibrium di mana kehidupan menjadi tenteram dan damai tanpa diusik oleh kritik dan oposisi. Menurut Marx, tidak adanya kritik yang timbul bukan karena ketidakberdayaan atau karena adanya otoritas yang dominan, tetapi karena kritik memang sudah tidak diperlukan karena tujuan masyarakat sudah tercapai. Di stadium ini terwujud masyarakat sosialisme dengan penuh ketentraman dan kedamaian. Namun pandangan Marx tersebut sangat otopis karena tidak sesuai bagi kodrat manusia sebagai makhluk yang dinamis.

Berbeda dengan Marx, Emile Durkheim ( lahir di Epinal, Francis tahun 1858) membagi masyarakat atas dua bagian, yaitu masyarakat mekanik dan masyarakat

\footnotetext{
${ }^{4}$ Lihat Charles Frankel, “Positifism “ dalam Vergilius Ferm,A History Of Philosophical Systems, newJersey :Littlefield Adams \& Co,1961, h.329

${ }^{5}$ Lihat Stephen K.Sanderson, Macrososilogy, Harper Collins Fublishers Inc.1991, h.221-222
} 
organic. ${ }^{6}$ Dalam masyarakat mekanik,kesadaran kolektif sangat kuat, mereka terikat dengan sangat sentiment, sentiment keagamaan, kesukuan dan tradisi leluhur yang menjadi pola normative. Masyarakat mekanik diwarnai oleh homogenitas yang demikian tinggi, individu larut dalam homogenitas sosial, sehingga individu "tidak berdaya " mengajukan pikiran-pikiran yang berbeda dengan norma kolektifitas yang dipandang mapan.

Sebaliknya, dalam masyarakat organik, heteroganitas sosial nampak jelas. Ruang gerak individu-individu untuk menentukan orientasi hidupnya mendapat peluang besar. Individu-individu berhak memiliki pendapat sendiri yang berbeda dengan apa yang selama ini dipandang mapan. Karena itu, kritik-kritik sosial mendapat penghargaan yang tinggi sebagai sumber dinamika sosial. Dalam masyarakat organic, spesialisasi fungsi-fungsi mewarnai struktur masyarakat. Karena itu terdapat saling ketergantungan sosial antar individu. Keanekaan fungsi-fungsi sosial menyebabkan terjadinya ketergantungan sosial antar elemen masyarakat, disini terbentuk system sosial organic yang bercorak structural fungsional.

Max Weber (lahir di Erfurt, Jerman tahun 1864 ) mengemukakan dua bentuk masyarakat, yaitu masyarakat non-rasional dan masyarakat rasional. Masyarakat non rasional ditandai oleh dua bentuk kepemimpinan, yaitu kepemimpinan tradisional dan kepemimpinan karismatik atau menurut Weber di sebut otoritas tradisional dan otoritas karismatik. Otoritas tradisional berlandaskan pada kekudusan tradisi yang diwarisi dari leluhur. Otoritas tradisional dibedakan atas tiga hal, yaitu :

\section{Gerontokrasi}

2. Patrikalisme

\section{Patrimonalisme. ${ }^{7}$}

Otoritas gerontokrasi dimiliki oleh para tertua-tertua atau yang dituakan yang memegang wewenang dan menentukan garis kebijakan sosial. Otoritas patrikalisme dipegang oleh sekelompok orang yang memiliki hubungan keterlibatan ( semacam nepotisme), sedangkan otoritas patrimonalisme dipegang oleh sekelompok orang yang

\footnotetext{
( London : Cambridge University Press, 1981 ),h.142 Capitalism and Modem Sosial Theory,, Anthony Giddens ${ }^{6}$

${ }^{7}$ Lihat Doyle Paul Johnson, Sosiological Theory Classical Founders and contemporary Perspektive, ( London : John Weley and Sons,Inc., 1981),h.211-222
} 
memiliki hubungan pribadi yang intim (semacam koncoisme). Ketiga bentuk otoritas tersebut sangat mempertahankan status-quo, sehingga sulit menerima kritikan sosial. Mereka berusaha membentuk opini yang memberikan legitimasi atas kekuasaan yang dimiliki.

Otoritas karismatik didasarkan pada kemampuan dan mutu yang dipandang "luar biasa" yang dimiliki oleh seseorang. Ia memiliki semacam kekuatan "adidaya " yang mendominasi seluruh kekuatan yang ada. Kekuatan lain hampir tidak berdaya didepan sang tokoh karismatik. Sehingga tidak saja kemampuan mengeritik tidak ada tetapi kehendak mengeritik pun tidak akan timbul, Pemimpin karismatik juga sangat mempertahankan status-quo sehingga menepis segala kemungkinan kritik sosial yang timbul.

Dalam masyarakat rasional ditandai dengan kepemimpinan legal-rasional atau otoritas legal-rasional. Yang dimaksud dengan legal-rasional adalah undang-undang yang diproduksi oleh rakyat yang menjadi dasar acuan yang menentukan ditetapkannya seorang pemimpin. ${ }^{8}$ Pemimpin (otoritas ) rasional tersebut identik dengan pemimpin demokratis. Dalam masyarakat demokratis bursa pendapat selalu ditawarkan kepada masyarakat untuk memberikan kritik konstruktif terhadap kondisi yang berkembang.

Dari uraian di atas dapat dipahami bahwa masyarakat mitis dalam teori Comte, masyarakat sosialisme dalam teori Marx, masyarakat mekanik dalam teori Durkheim dan masyarakat non-rasional dalam teori Weber : kritik sosial hampir tidak terjadi, warga masyarakat hampir "tidak mempunyai pendapat" atas situasi yang berkembang. Mereka menyerahkan sepenuhnya kepada pemimpinnya dalam menentukan nasib mereka. Sebaliknya dalam masyarakat positif menurut Comte, masyarakat proletariat menurut Marx, masyarakat organic menurut Durkheim dan masyarakat rasional menurut Weber : didalamnya terdapat peluang yang besar akan munculnya kritik-kritik sosial.

\section{B. Epistimologi Kritik Sosial}

Era reformasi dewasa ini semakin memberi peluang bagi masyarakat modern menjadi masyarakat yang terbuka (the open society). Karena itu, kritik-kritik sosial yang konstruktif dapat memperkaya wacana dialog cultural dalam masyarakat.

\footnotetext{
${ }^{8}$ Bryn Turner, Weber And Islam A, Critical Study, (London \& Boston : Routlege \& Kegan Paul, 1974),h.75-76
} 
Pertanyaan yang timbul adalah bagaimana sesungguhnya kritik-kritik itu muncul dalam masyarakat yang penuh dinamika. Karl R. Popper seorang pencetus rasionalisme-kritis mengajukan konsep kritisismenya dengan metode falsifikasionistik, bukan verifikasionistik. Menurut Popper, bila seorang menghadapi suatu hal dan hal tersebut sudah benar, maka kita biarkan untuk sementara dan dapat diterapkan sebagai solusi tentatif sambil terus mengamati aksi dan reaksi yang ditimbulkan sampai ditemukan titik kesalahan yang timbul dalam proses kerjanya. Jadi, epistimologi Popper bertendensi “ mencari-cari tahu kesalahan" bukan mencari pembenaran. ${ }^{9}$ Sebab, bila sehari-hari seseorang hanya terus-menerus membenarkan ia akan terseret ke dalam fanatisme dan absolutism. Falsifikasi berperan " mencairkan " apa yang selama ini dibakukan atau merelatifkan apa yang selama ini diabsolutkan, sehingga terjadi dinamika dan perubahan melalui koreksi dan kritik.

Pernyataan yang timbul terhadap pendapat Popper tersebut adalah : Bila Popper mengabaikan verifikasi, maka bagaimana kita mengatakan teori dan kebijakan itu benar terutama bila diaplikasikan secara praktis dan ternyata memberikan manfaat bagi masyarakat. Popper pada dasarnya tidak mengabaikan pembenaran, tetapi pembenaran itu sifatnya tentative (sementara). Jadi, Neo-Positivisme Ayer menganut paham verifikasionistik, sedangkan rasionalisme-kritis Popper menganut paham falsifikasionistik.

Alions Taryadi mengomentari efek positif dari rasionalisme-kritis Karl Popper untuk diterapkan di Indonesia. Di Indonesia menurut Taryadi telah berkembang dengan suburnya cara berfikir yang berakar pada subyektifisme. Argumentasi banyak didasarkan pada perasaan dan rasa keyakinan pribadi. Orientasi pada otoritas sangat kuat mewarnai cara orang mendekati masalah. Di samping itu, dari ucapan-ucapan yang sering terlontar , tampak kurangnya pemahaman terhadap fungsi kritik sebagai elemen penting dalam mekanisme pertumbuhan pengetahuan ( teori atau kebijaksanaan ) sebagai upaya pemecahan masalah. Kritik seringkali semata-mata dipandang sebagai suatu ketidakpuasan terhadap suatu kebijaksanaan dengan akibat menjatuhkan pribadi pendukung kebijaksanaan yang bersangkutan. Sikap seperti ini diperlukan penataan pola pikir yang 
terbuka atas kritik, perubahan dan perbedaan pendapat. Sebab, semakin maju suatu masyarakat atau bangsa, maka diferivikasi dan aneka pendapat amat sulit dihindari. ${ }^{10}$ Pancasila sebagai falsafah hidup bangsa Indonesia adalah system terbuka atas perubahan yang konstruktif. Pancasila memberikan peluang bagi open-society ( masyarakat terbuka) bukan masyarakat yang terisolir dari "bursa " pendapat.

Muhammad Arkoun, seorang pemikir muslim pasca-modern mengemukakan teori kritis yang disebutnya dengan teori dekonstruksi. Teori dekonstruksi Arqoun berupaya memisahkan antara absolute dengan yang relative atau yang Ilahy dengan yang insaniy. Wahyu yang bersifat Ilahiyah sedangkan pemahaman manusia terhadapnya bersifat insaniyah. Mencampurkan antara Ilahiyah dengan insaniyah adalah suatu anarki. Kenyataan dalam sebagian masyarakat Islam terhadap kecenderungan memutlakkan hasil pemikirannya sehingga kebijakan yang di ambil cenderung dipaksakan untuk diterima oleh orang lain.

Bila dilihat dalam konteks sosial, pandangan Muhammad Arkoun tersebut menunjukkan bahwa kebijakan sosial harus selalu terbuka untuk kritik. Otoritarianisme kebijakan sosial tidak sesuai dengan ruh Islam. Karena Islam selalu menghendaki ishlah, yakni pembaharuan yang perlu dilakukan terhadap tatanam yang sudah tidak sejalan dengan kehendak zaman.

\section{Tinjauan Dakwah}

Alquran dan hadis merupakan sumber utama ajaran Islam, didalamnya menginformasikan kepada umat Islam bahwa sesungguhnya dakwah menempati posisi utama, strategis dan menentukan. Boleh dikata bahwa dakwah adalah urat nadinya Islam, bila dakwah tidak tegakkan, maka sama dengan memotong urat nadinya Islam, artinya Islam akan dimatikan. Dakwah ibarat jantungnya Islam kapan berhenti berdenyut maka tunggulah kehancurannya.

Dakwah ditinjau dari segi etimologi berasal dari bahasa Arab, yang berarti” panggilan, ajakan atau seruan" dalam ilmu tata bahasa Arab kata dakwah berbentuk sebagai “isim masdar” yakni dari kata " دعا يدعوا دعوة artinya memanggil, mengajak atau menyeru.

${ }^{10}$ Alfions Taryadi, Epistimologi Pemecahan Masalah Menurut Karl R.Popper (Jakarta: PT. Gramedia,1959),h.Xiii 
Pengertian dakwah menurut istilah, mengandung beberapa arti yang beragam dikarenakan sudut pandang para ahli berbeda. Antara lain Asmuni Syukir dalam bukunya “Dasar-Dasar Strategi Dakwah Islam" memberikan pengertian istilah dakwah dari dua sudut pandang, yakni pengertian dakwah yang bersifat pembinaan yang diartikan suatu kegiatan mempertahankan dan menyempurnakan sesuatu yang telah ada sebelumnya. Sedangkan dakwah yang bersifat pengembangan diartikan suatu kegiatan yang mengarah kepada pembaharuan. ${ }^{11}$

Dakwah bermakna seruan ,ajakan, panggilan kepada jalan yang dikehendaki oleh Islam. Dengan demikian, dakwah merupakan proses komunikasi kepada manusia baik individu maupun sosial, agar beriman dan beramal sesuai dengan ajaran Islam. Dakwah mempunyai beberapa peran, yakni :

1. Takhabbur, yakni memberitakan ajaran-ajaran kepada masyarakat agar mereka dapat memahami dan menaruh komitmen dan mengamalkan ajaran Islam.

2. Ishlah, yakni memperbaiki, menata dan mereformasi kondisi-kondisi yang ada kepada semua tatanan yang diwarnai ajaran Islam.

3. Irtifa' yakni berupaya meningkatkan atau mengupgarade kondisi-kondisi yang sudah baik menuju kondisi yang lebih baik, lebih konstruktif dan lebih prospektif.

4. Tafriq, yakni mengisolasi kondisi-kondisi yang negative dari yang positif agar yang positif tumbuh dan berkembang secara progresif tanpa dihambat oleh rintangan-rintangan yang destruktif.

Bila dilihat peran dakwah tersebut diatas, maka kritik sosial sejalan dengan alTafriq. Kata "kritik " itu sendiri secara harfiah juga berarti " memisahkan" memisahkan yang benar dari yang salah. Makna tersebut sejalan pula dengan salah satu nama alqur'an, yaitu al-Furqan, yang berarti memisahkan antara yang haq dengan yang bathil. Dari makna tersebut nampak bahwa keberadaan Islam merupakan langkah kritis terhadap agama, tradisi sosial serta tatanan yang berlaku pada masa pra Islam. Bahkan dimanapun Islam berada selalu bersikap kritis terhadap situasi yang berkembang.

Bila dilihat dari segi dakwah sebagai bagian dari kritik sosial, maka kritik sosial berperan untuk :

${ }^{11}$ Asmuni Syukir, Dasar-Dasar Strategi Dakwah Islam, ( Surabaya :Al-Ikhlas, 1983),h.20 
1. Sebagai koreksi untuk rekonstruksi tatanan sosial. Sesuai dengan cita dakwah, kritik sosial sejalan dengan prinsip amar-ma'ruf nahi munkar. Koreksi dan kritikan yang muncul bertujuan menata kembali (merekonstruksi) tatanan sosial yang ada yang dilandasi oleh ruh Islam.

2. Melembagakan sikap kritis dalam masyarakat Islam. Dakwah sebagai proses aktualisasi ajaran Islam, maka seorang da'I dituntut memiliki kepekaan sosial. Dengan kepekaan sosial, da'i dapat memiliki kemampuan yang proaktif dalam mengantisipasi masalah yang timbul dalam masyarakat. Kenyataan menunjukkan bahwa para tokoh Islam dewasa ini sering kali bersifat reaktif dari pada proaktif, sehingga masalah yang timbul tidak dapat diantisipasi sebelum munculnya. Dengan pelembagaan sikap kritis itu tidak hanya para tokoh yang memiliki kepekaan, tetapi juga masyarakat umum dapat mengembangkan daya kritisnya terhadap problema yang timbul dalam masyarakat.

3. Mengembangkan sikap terbuka dan lapang dada. Kritis sosial yang berkembang subur dalam masyarakat akan membuka ketertutupan dan kejemudan masyarakat. Hal tersebut menjadi pra-kondisi bagi terciptanya sikap tasamuh ( toleran) menuju masyarakat yang tentram dan damai.

Kritik sosial bukan sekadar melontarkan sorotan sebagai pernyataan ketidakpuasan, melainkan harus berdasar pada beberapa hal sebagai berikut :

1. Kritik itu objektif, artinya kritik yang tidak didasarkan atas kemauan subyek ( pribadi ) melainkan didasarkan atas fakta-fakta sosial yang akurat.

2. Kritik itu rasional, tidak didasarkan pada terkaan rasa dan pemahaman emosional kritik. Kritik yang emosional sering kali menyeret ke suasana distruktif.

3. Kritik dimaksudkan untuk mengabdi kepada kebenaran, artinya bukan untuk kepentingan dan tendensi meraih kepentingan pribadi dan golongan, melainkan untuk mencerminkan dan mempertahankan kebenaran.

4. Kritik disampaikan secara terbuka dan bertanggung-jawab, artinya kritikan yang dilontarkan tak sembunyi-sembunyi, melainkan secara terbuka untuk diuji dan diferifikasi orang lain. Pemilik kritik mempertanggungjawabkan kritikannya yang disertai fakta empiris atau berlandaskan teori ilmiyah yang solid. 
Islam sebagai agama dakwah haruslah memiliki pendekatan dan kemampuan dalam merespon dinamika masyarakat modern kontenporer. Hal ini menjadi suatu keharusan historis, sebab era globalisasi dan informasi memaksa masyarakat dunia untuk berpikir rasional, kritis, analitis dan obyektif dalam mensikapi perkembangan realitas sosial.

Proses modernisasi sebagai bagian dari pencerahan masyarakat, ternyata berimplikasi pada nilai-nilai sosial budaya dan berakhir pada munculnya problema baru dalam kehidupam manusia khususnya umat Islam.

Fenomena sosial tersebut, Brifanet berpendapat dalam Dadang Kahmad bahwa peradaban masyarakat modern telah menelantarkan dan mereduksi nilai-nilai kemanusiaan yang esensial manusia, sehingga manusia modern banyak teralienasi dari eksistensinya dan mengalami keterasingan jiwa. ${ }^{12}$

Dakwah sebagai sebuah komitmen moral dari seorang hamba yang cinta akan Rabb-Nya menjadi suatu condition sine quanon ( sangat penting ) yang tak mungkin dihindarkan dalam kehidupan, karena tegak dan suburnya nilai-nilai Islam di seluruh belahan bumi tergantung dari usaha yang suci ini.

Esensi dakwah dalam sistem sosio-kultural adalah mengadakan dan memberikan arah perubahan. Mengubah struktur masyarakat dan budaya dari kedhaliman ke arah keadilan, keterbelakangan ke arah kemajuan yang semuanya dalam rangka meningkatkan derajat manusia dan masyarakat kearah puncak kemanusiaan. Kenyataan sejarah membuktikan bahwa kehadiran Islam sebagai agama yang peka terhadap kehidupan sosial mampu menggerakkan perubahan sosio-kultural secara mendasar sesuai dengan tingkat peradaban dan masalah yang berkembang ketika itu.

Dakwah Islam sebagai agent of change memberikan dasar filosofi " eksistensi diri” dalam dimensi individual, keluarga dan sosio-kultural sehingga muslim memiliki kesiapan untuk berinteraksi dan menafsirkan kenyataan-kenyataan yang dihadapi secara mendasar dan menyeluruh menurut ajaran Islam. Jadi Islam yang telah internalized menjadi paradigma untuk memberi struktur dan makna terhadap realitas sosial dan fisik serta menjadi kerangka dasar pemecahan masalah. Oleh karena perubahan sosial menuju pada arah tertentu, maka dakwah Islam berfungsi mengkritisi, memberikan arah dan corak ideal

\footnotetext{
${ }^{12}$ Dadang Kahmad, Sosiologi Agama, (Bandung : Pustaka Setia, 2000),h.30
} 
tatanan masyarakat baru yang akan datang. Aktualitas dakwah berarti upaya penataan masyarakat terus-menerus di tengah-tengah dinamika perubahan sosial sehingga tidak ada satu sudut kehidupanpun yang lepas dari perhatian dan penggarapannya. Dengan demikian dakwah Islam senantiasa harus bergumul dengan kenyataan baru yang pemunculannya kadang kala sulit diperhitungkan sebelumnya. ${ }^{13}$

Bila dicermati berbagai perubahan sosial dikaitkan dengan kecenderungan baru kebangkitan Islam pada decade terakhir ini, maka akan ditemukan tiga indikasi yang menonjol yaitu :

1. Munculnya keingainan segenap umat Islam untuk dapat meresponi era pembangunan bangsa lebih kreatif dengan semangat reformasi dengan tetap pada bingkai keislaman.

2. Munculnya kesadaran yang semakin mengkristal dan meluas mengenai perlunya pemahaman Islam baru secara lebih intelektual dan rasional.

3. Munculnya keinginan agar respons dan pemahamannIslam yang baru itu tetap tidak mau melupakan jati dirinya sebagai manusia yang berbudaya. ${ }^{14}$

Ketiga kecenderungan di atas, tampaknya mengacu pada satu cita-citra bersama, yakni agar umat Islam di masa depan bisa lebih maju dan berkembang. Untuk mencapai cita-cita itu, perlu menempatkan fungsi dakwah, yakni sebagai agen perubahan dan terus mendorong terciptanya reformasi menyeluruh dalam sosial kemasyarakatan sebagai suatu keharusan.

Untuk menciptakan perubahan cara berfikir, bersikap dan bertindak manusia, baik pada dataran realitas sosial individu maupun sosio-kultural dalam rangka mengusahakan terwujudnya ajaran Islam dalam semua segi kehidupan dengan pendekatan tertentu. ${ }^{15}$

Dalam dunia Islam, terdapat beberapa peristiwa yang patut disebut sebagai gerakan perubahan sosial (kritik sosial) atau tanda kebangkitan Islam (gerakan amar ma'ruf nahi mungkar). Antara lain bangkitnya Ayatullah Khumaeni yang berhasil menumbangkan monarkhi Iran dan menggantikan system pemerintahan Islam. Demikian juga kehadiran Ziaul-Haq di pentas politik Pakistan dapat menumbangkan dan menggantung Zul Fikar Ali Bhuto, kemudian berusaha menerapkan ajaran yang menurut pendapatnya adalah ajaran Islam murni. Antara lain, hukuman cambuk terhadap orang yang melakukan zina.

${ }^{13}$ Lihat Amrullah Ahmad, Dakwah Islam dan Perubahan Sosial, ( Yogyakarta : Prima Duta, 1983),h.17

${ }^{14}$ Syahri Harahap, Islam Dinamis ( Cet.I, Yogyakarta : PT. Tiara wacana,1997),h.89

${ }^{15}$ Lihat Amrullah Ahmad, Op.Cit.,h.2 
Di Sudan kebangkitan Islam di tandai dengan bangkitnya Jafar Nimeri yang berusaha menerapkan ajaran Islam, antara lain mengharamkan peredaran minuman keras dan pemotongan tangan dan kaki secara bersilang bagi pencuri. ${ }^{16}$

Apa yang dilahirkan oleh para pembaharu-pembaharu itu, adalah sebagai manifestasi dari kritik sosial dalam tatanan peradaban kemanusiaan dengan harapan terealisasinya realitas sosial berupa : khaerul fardhiyah (pribadi yang baik), khaerul usrah (keluarga yang baik), khaerul jamaah (jamaah yang baik), khaerul ummah (umat yang baik). Tatanan sosial yang religius dan manusiawi, hanya mungkin dicapai jika ada kesadaran baik secara individu maupun secara kolektif untuk melakukan dakwah Islam atau mengkritisi dalam segala dimensi kehidupan manusia.

\section{Kesimpulan}

Kritik sosial merupakan wahana bagi perubahan sosial dan pra- syarat menciptakan masyarakat dinamis. Kritik sosial berperan mengoreksi praktek-praktek yang berlaku ditengah-tengah kehidupan masyarakat, apakah sesuai dengan norma-norma agama, sosial budaya, politik dan sebagainya atau tidak. Proses ini terdiri dari pengubahan sistem merasa, berfikir, bersikap dan bertindak. Tidak hanya menyampaikan kebenaran, tetapi harus bersikap kritis dan mengoreksi penyimpangan-penyimpangan dalam masyarakat.Tanpa kritik sosial, maka kondisi masyarakat hanya mempertahankan statusquo, sehingga menjadi apatis tanpa dinamika yang konstruktif.

Kritik sosial merupakan sifat berbeda pendapat yang muncul dari penilaian yang kritis terhadap situasi. Perbedaan pendapat tersebut sangat diperlukan demi menjaga penyalahgunaan wewenang dalam menjalankan fungsinya.

Jika kritik sosial diimplementasikan dalam kehidupan masyarakat, maka akan lahir pengertian amar ma'ruf nahi mungkar, sedang amar ma'ruf nahi munkar merupakan salah satu konsep yang sangat urgen dalam Alquran karena berkaitan langsung dengan hakekat keberagamaan Islam.

Dakwah bermakna “al-Tafriq”, yakni mengisolasi kondisi-kondisi yang negative dari yang positif agar yang positif tumbuh dan berkembang secara progresif tanpa dihambat oleh rintangan-rintangan yang destruktif. Dakwah dalam hal ini harus pro aktif mengantisipasi masalah yang muncul dan memberikan alternative pemecahannya, sehingga

${ }^{16}$ H.A. Mukti, 70 Tahun Prof. DR.HM. Rasyidi ( Cet. I : Harian Umum Pelita, 1985 ),h. 291 
dakwah benar-benar menjadi agen perubahan sosial pada kemajuan bukan pengekor kemajuan.

\section{DAFTAR PUSTAKA}

Azyumardi Azra, Memunju masyarakat Madani : Gagasan, Fakta dan tantangan, Cet. I : Bandung : PT.Remaja Rosda Karya, 1999

Muh. Hasim Kamali, Kebebasan berpendapat Dalam Islam, Cet.I : Bandung : Mizan, 1996

Fahmi Huwaidi, Demokrasi, Oposisi dan Msyarakat Madani, Isu-isu Besar Politik Islam, Cet.I : Bandung : Mizan, 1999

Syekh Syaukat Husain, Hak Asasi Manusia Dalam Islam, Cet. I : Jakarta : Gema Insani Press, 1996

Ali Zawawi Dan Saifullah Ma'shum, Penjelasan Alquran tentang Kritik Sosial, Ekonomi dan Politik, Cet. I : Jakarta : Gema Insani Press, 1999

Muhammad Husain Fadlullah, Metodologi Dakwah Dalam Alquran Pegangan Bagi

Para Aktifis, Cet. I : Jakarta : PT. Lentera Besritama,1997

Muhammad Wahyuni Nafis, Rekonstruksi Dan Renungan : Religius Islam, Cet. I : Jakarta : Paramadina, 1996

Sahar L Hasson (Ed) Memilih Partai Islam Visi dan Persepsi, Cet.I, Jakarta : Gema Insani Pres, 1998

Charles Frankel, "Positifism " dalam Vergilius Ferm, A History Of Philosophical Systems, newJersey : Littlefield Adams \& Co,1961

Amin Rais, Membangun Politik Adi Luhung, Membumikan Tauhid Sosial Menegakkan Amar

Ma'ruf Nahi Mungkar Cet. I : Bandung : Zaman Wacana Mulia, 1998

Charles Frankel, "Positifism " dalam Vergilius Ferm,A History Of Philosophical Systems, newJersey :Littlefield Adams \& Co,1961, h.329

Stephen K.Sanderson, Macrososilogy, Harper Collins Fublishers Inc.1991

Anthony Giddens, Capitalism and Modem Sosial Theory, London : Cambridge University Press, 1981

Doyle Paul Johnson, Sosiological Theory Classical Founders and contemporary Perspektive,

London : John Weley and Sons,Inc., 1981

Bryn Turner, Weber And Islam A, Critical Study, London \& Boston : Routlege \& Kegan Paul, 1974

Paul Arthur Schilpp, “Karl Popper, Autobiography” dalam Paul Arthur Schipp (ed), The

Philosophy Of Karl Popper, Book I, La Salle Illionis Open Court,1974

Alfions Taryadi, Epistimologi Pemecahan Masalah Menurut Karl

R.Popper Jakarta: PT. Gramedia,1959

Asmuni Syukir, Dasar-Dasar Strategi Dakwah Islam, Surabaya : Al-Ikhlas, 1983

Dadang Kahmad, Sosiologi Agama, Bandung : Pustaka Setia, 2000

Amrullah Ahmad, Dakwah Islam dan Perubahan Sosial, Yogyakarta : Prima Duta, 1983

Syahri Harahap, Islam Dinamis Cet. I, Yogyakarta : PT. Tiara wacana,1997

Amrullah Ahmad, Op.Cit.,h.2

H.A. Mukti, 70 Tahun Prof. DR.HM. Rasyidi, Cet. I : Harian Umum Pelita, 1985 